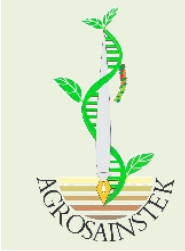

\title{
AGROSAINSTEK
}

\section{Jurnal Ilmu dan Teknologi Pertanian}

Website jurnal : http://agrosainstek.ubb.ac.id

Artikel Penelitian

\section{Determinasi Pengaruh Populasi Walang Sangit (Leptocorisa oratorius Fabricius) terhadap Hasil Gabah Padi Sawah di Desa Kimak, Kecamatan Merawang, Kabupaten Bangka}

\section{The Effect of Rice Bug Population (Leptocorisa oratorius Fabricius) on Paddy Yield in Kimak Village, Merawang District, Bangka Regency}

\author{
Winarsi $^{1 *}$, Sitti Nurul Aini ${ }^{1}$, Rion Apriyadi ${ }^{1}$ \\ ${ }^{1}$ Jurusan Agroteknologi, Fakultas Pertanian Perikanan dan Biologi, Universitas Bangka Belitung. \\ Jalan Raya Balunijuk, Bangka, 33172
}

Diterima : 7 Maret 2018/Disetujui : 8 Mei 2018

\begin{abstract}
Rice crops are the main source of staple food for the Indonesian people, as well as in the Bangka Belitung province. The cultivation of rice crops is still through various obstacles, such as the attack of Leptocorisa oratorius Fabricius, which attacks the rice plants after flowering by sucking the grain. The aim of this study was to know the effect of L.oratorius population on the rice yield, to know the number of L. oratorius that can decrease the $15 \%$ paddy yield and to know the percentage of rice loss based on the number of L. oratorius population in the Kimak village, Merawang district, Bangka regency. The research was conducted on November 2017 to January 2018 on the paddy field in Kimak village. This research used the experimental method with Completely Randomized Design (CRD) which consist of 8 treatments and 2 replications. The treatment was the differences L.oratorius population. Consist of: without L.oratorius, 2 L.oratorius, 3 L.oratorius, 4 L.oratorius, 5 L.oratorius, 6 L.oratorius, 7 L.oratorius and 8 L.oratorius. The result showed that the number of L. oratorius has the significant effect on rice yield, 3 population of L. oratorius per $50 \mathrm{~cm} \times 50 \mathrm{~cm}$ able to reduce the rice yield by $15 \%$ and the percentage of yield loss at the treatment of 2 - 8 L.oratorius is about $10.97 \%$ up to $28.98 \%$.
\end{abstract}

Keywords: L. oratorius; population; paddy; yield loss

\section{ABSTRAK}

Tanaman padi merupakan sumber utama makanan pokok bagi masyarakat Indonesia, begitu pula di Provinsi Bangka Belitung. Budidaya tanaman padi masih melalui berbagai kendala, salah satunya adalah hama walang sangit (Leptocorisa oratorius Fabricius), yang menyerang tanaman padi setelah berbunga dengan mengisap gabah. Tujuan penelitian ini adalah untuk mengetahui pengaruh populasi L.oratorius terhadap hasil padi, untuk mengetahui jumlah L. oratorius yang dapat menurunkan hasil padi 15\% dan untuk mengetahui persentase kehilangan beras berdasarkan jumlah populasi L.oratorius di desa Kimak, Kecamatan Merawang, Kabupaten Bangka. Penelitian dilakukan pada bulan November 2017 sampai Januari 2018 di sawah di desa Kimak. Penelitian ini menggunakan metode eksperimen dengan Rancangan Acak Lengkap (RAL) yang terdiri dari 8 perlakuan dan 2 ulangan. Perlakuannya adalah perbedaan populasi L.oratorius. Terdiri dari: tanpa L.oratorius, 2 L.oratorius, 3 L.oratorius, 4 L.oratorius, 5 L.oratorius, 6 L.oratorius, 7 L.oratorius dan 8 L.oratorius. Hasil penelitian menunjukkan bahwa jumlah L.oratorius berpengaruh nyata terhadap hasil padi, 3 populasi L.oratorius per $50 \mathrm{~cm} \times 50 \mathrm{~cm}$ mampu menurunkan hasil padi sebesar 15\% dan persentase kehilangan hasil pada perlakuan 2 - 8 L. oratorius sekitar 10,97\% sampai dengan 28,98\%.

Kata kunci: populasi; L. Oratorius; padi; kehilangan hasil 


\section{Pendahuluan}

Padi (Oryza sativa L) merupakan salah satu tanaman pangan utama di Indonesia. Produksi padi sawah di Indonesia menurut data Kementrian pertanian (2018) pada tahun 2013 sampai tahun 2017 terus meningkat. Berdasarkan peningkatan produksi padi sawah yang ada, produksi padi sawah untuk tahun 2017 dalam data sementara telah mencapai sebesar 77.294 ton, meningkat dibandingkan dari 2 tahun terakhir, yakni tahun 2015 sebanyak 71.766 ton/ha dan tahun 2016 sebanyak 75.483 ton/ha.

Provinsi kepulauan Bangka Belitung merupakan salah satu daerah di Indonesia yang cukup aktif dalam memproduksi tanaman padi. Produksi padi sawah di provinsi kepulauan Bangka Belitung tahun 2016 mencapai 23.941 ton/ha (Kementan 2018). Bangka Belitung memiliki beberapa sentra sawah, salah satu diantaranya adalah di Desa Kimak, Kecamatan Merawang Kabupaten Bangka. Badan Pusat Statistik Provinsi Kepulauan Bangka Belitung (2017) menyatakan bahwa, luas wilayah Kabupaten Bangka sebesar 295.064 Ha, dengan lahan pertanian sekitar $112.284 \mathrm{Ha}$, dan potensi lahan sawah 4.410 Ha. Lahan sawah yang telah tercetak pada tahun 2016 seluas $2.200 \mathrm{Ha}$, termasuk di Desa Kimak seluas $311 \mathrm{Ha}$.

Ketersediaan lahan yang memadai menunjukkan bahwa tanaman padi memiliki potensi untuk dikembangkan dan dibudidayakan secara terus menerus. Usaha budidaya tanaman padi sampai saat ini masih menghadapi berbagai kendala, beberapa diantaranya adalah hama dan penyakit serta serangan organisme pengganggu tanaman (OPT) yang dapat menurunkan hasil produksi tanaman padi.

Hama tanaman padi yang umum dijumpai salah satunya adalah walang sangit. Walang sangit (Leptocorisa spp.), (Hemiptera: Alydidae) adalah hama yang menyerang tanaman padi setelah berbunga dengan cara menghisap cairan bulir padi menyebabkan bulir padi menjadi hampa atau pengisiannya tidak sempurna. Baik nimfa dan dewasa, walang sangit menghisap cairan daun, biji padi yang muda dan padi masak susu untuk nutrisi selama daur hidupnya. Daur hidup rata-rata walang sangit diantara tanaman padi, dari fase telur hingga serangga dewasa mati adalah selama $\pm 60,33$ hari (Dutta \& Roy 2016). Walang sangit yang dewasa berbentuk langsing dan panjangnya sekitar 17-19 $\mathrm{mm}$, dengan bagian perut berwarna hijau atau krem dan pada punggungnya berwarna coklat kehijauhijauan (Pimsen et al. 2013.).

*Korespondensi Penulis.

E-mail: winarsisheshie079@gmail.com (Winarsi)
Walang sangit (L. oratorius) merupakan hama potensial yang dapat menyebabkan kehilangan hasil panen padi hingga sebesar 50\% (Sihombing 2015). Dinas pertanian provinsi Riau dalam Purnomo (2013) menyatakan bahwa batas ambang ekonomi populasi walang sangit (Leptocorisa spp.) dengan cara pengamatan langsung adalah 5 ekor/ 1 $\mathrm{m}^{2}$. Sementara menurut Santoso (2015) bila dalam setiap meter persegi $\left(\mathrm{m}^{2}\right)$ terdapat 5-7 ekor walang sangit, maka dikatakan populasi yang tinggi. Hasil penelitian Mustikawati dan Asnawi (2011) menyatakan bahwa serangan walang sangit 5 ekor/ 9 rumpun padi akan menurunkan hasil 15\%.

Serangan hama walang sangit pada tanaman padi dapat mengakibatkan penurunan kualitas maupun kuantitas hasil. Serangan yang terjadi sebelum matang susu menyebabkan gabah hampa sampai tidak berbuah kembali, gabah yang hampa akan mudah pecah jika masuk dalam penggilingan (Lestari 2017), sedangkan serangan pada saat bulir telah berisi sampai menjelang masak menyebabkan gabah berwarna buram sehingga kualitasnya rendah (Purwaningsih et al. 2018). Pratimi dan Soesilohadi (2011) menyatakan beberapa gejala yang ditimbulkan akibat serangan hama walang sangit diantaranya, terdapat spot titik hitam hasil tusukan alat penghisap cairan padi oleh walang sangit, malai yang dihisap menjadi hampa dan berwarna coklat kehitaman.

Berdasarkan hasil dari beberapa penelitian yang pernah dilakukan, maka diduga terdapat pengaruh antara populasi walang sangit dengan penurunan hasil gabah padi sawah. Menghadapi fenomena tersebut, maka penelitian ini dilakukan sebagai langkah untuk mengetahui populasi hama walang sangit yang bisa menyebabkan kerusakan dan penurunan hasil pada gabah kering padi sawah dengan perlakuan populasi walang sangit yang berbeda.

\section{Bahan dan Metode}

\section{Bahan dan Alat}

Penelitian ini telah dilaksanakan pada bulan November 2017 sampai dengan bulan Januari 2018. Penelitian ini dilaksanakan di lahan padi sawah unit Balai Penyuluh Pertanian, Perikanan dan Kehutanan (BP3K), yang terletak di desa Kimak, Kecamatan Merawang, Kabupaten Bangka, Provinsi Kepulauan Bangka Belitung.

Alat yang digunakan dalam penelitian ini berupa kantong plastik, gunting, pisau, insect net, tali plastik (rafia), alat ukur (meteran), kertas label nama, kamera, kaca pembesar (lup), alat tulis, dan lembar pengamatan. Bahan yang digunakan yaitu 
tanaman padi varietas Inpago 8 , walang sangit (Leptocorisa oratorius F.), dan pestisida (bahan aktif fipronil, propoksur dan metolkarb).

\section{Metode Penelitian}

Metode yang digunakan pada penelitian ini yaitu metode penelitian eksperimen. Penelitian ini menggunakan Rancangan Acak Lengkap (RAL). Perlakuan terdiri dari 8 perlakuan dan 2 kali ulangan pada masing-masing percobaan, sehingga terdapat 16 plot. Plot yang digunakan berukuran 50 $\mathrm{cm} \times 50 \mathrm{~cm}$, yang terdiri dari 8 rumpun tanaman. Perlakuan yang digunakan adalah sebagai berikut: $\mathrm{W} 0=$ Kontrol (Tanpa Walang sangit), W1= Walang sangit 2 ekor per plot, W2= Walang sangit 3 ekor per plot, W3= Walang sangit 4 ekor per plot, $\mathrm{W} 4=$ Walang sangit 5 ekor per plot, W5=Walang sangit 6 ekor per plot, W6= Walang sangit 7 ekor per plot, dan W7= Walang sangit 8 ekor per plot.

\section{Peubah yang diamati:}

\section{Intensitas kerusakan mutlak}

Intensitas kerusakan mutlak dilakukan dengan cara mengumpulkan data sensus sampel yang diperoleh berdasarkan perhitungan jumlah gabah padi yang terserang hama secara mutlak dari semua gabah padi dalam setiap plot sampel. Menurut Natawigena (1989) dalam Napitu et al. (2012) analisis data dilakukan menggunakan rumus dan yaitu sebagai berikut:

$$
\mathrm{IKM}=\frac{a}{a+b} \times 100 \%
$$

Keterangan: IKM = Intensitas kerusakan mutlak; $\mathrm{a}=$ Jumlah tanaman sampel yang rusak (mutlak); b = Jumlah tanaman sampel yang tidak rusak

\section{Intensitas serangan hama}

Pengamatan intensitas serangan dilakukan secara visual berdasarkan gejala serangan walang sangit. Setiap plot di ambil seluruh rumpun tanaman padi untuk diamati. Rumpun tanaman padi yang sudah terlihat gejala serangannya di hitung satu, kemudian hitung berapa jumlah rumpun tanaman padi yang terserang dari sembilan rumpun tanaman padi yang diamati. Pengamatan dilakukan pada tanaman padi setelah dipanen. Masauna et al. (2013) menyatakan rumus penghitungan persentase intensitas serangan hama adalah sebagai berikut:

$$
\mathrm{P}=\frac{n}{N} \times 100 \%
$$

Keterangan: $\mathrm{P}=$ Persentase tanaman terserang hama; $\mathrm{n}=$ Jumlah gabah yang terserang hama walang sangit; $\mathrm{N}=$ Jumlah gabah yang diamati

Jumlah gabah padi bernas, hampa, dan terserang walang sangit per plot (butir)

Penghitungan jumlah gabah padi bernas, gabah hampa dan terserang walang sangit dilakukan setelah proses pemisahan setelah padi di panen.jumlah gabah bernas dipilih dengan cara menjepit gabah padi diantara telunjuk dan jari jempol, kemudian dihitung. Gabah akan dikatakan bernas jika bulir buah sudah benar-benar terisi penuh. Gabah padi hampa dilakukan dengan tahap yang sama seperti pengamatan padi bernas, yakni bisa dijepit menggunakan jari dan pengamatan secara visual, kemudian penghitungan jumlah gabah padi yang terserang hama walang sangit dilakukan dengan melihat ciri-ciri padi dengan gejala serangan walang sangit.

\section{Berat 100 biji (gram)}

Berat 100 biji diperoleh dengan mengambil gabah secara acak per perlakuan dan dihitung sebanyak 100 butir kemudian ditimbang dengan menggunakan timbangan digital.

\section{Intensitas kerusakan relatif}

Kerusakan pada tanaman tidak semua dapat dihitung dengan menggunakan rumus intensitas kerusakan mutlak, seringkali bentuk kerusakan yang tidak langsung (serangan tidak mutlak) atau mengalami kerusakan bertahap maka penilaian intensitas kerusakan dilakukan dengan pemberian skor yang menunjukan tahap kerusakan. Nilai skor kerusakan bertahap yang digunakan dalam penelitian ini adalah: $0=$ tidak ada kerusakan, $1=$ tingkat kerusakan $1-20 \%, 3=$ tingkat kerusakan, $21-40 \%, 5=$ tingkat kerusakan $41-60 \%, 7=$ tingkat kerusakan $61-80 \%$, dan $9=$ tingkat kerusakan $>80 \%$.

Selanjutnya untuk menghitung intensitas kerusakan relatif menurut Sudarjat (2008) dilakukan dengan menggunakan rumus:

$$
\mathrm{I}=\frac{\sum(n \times v) \times 100 \%}{Z \times N}
$$

Keterangan: $\mathrm{I}=$ intensitas kerusakan; $\mathrm{n}=$ jumlah sampel pada kategori kerusakan; $\mathrm{V}=$ nilai skor pada sampel; $\mathrm{N}=$ jumlah total sampel; $\mathrm{Z}=$ skor tertinggi dari katagori serangan 
Estimasi hasil produksi gabah dan kehilangan hasil akibat walang sangit

Estimasi adalah metode untuk memperkirakan nilai dari suatu populasi dengan menggunakan nilai dari sampel. Cara estimasi yang digunakan adalah dengan menggunakan pendekatan berat 100 butir biji. Kemudian melakukan penghitungan persentase gabah bernas, hampa dan terkena serangan walang sangit, serta estimasi kehilangan hasil gabah kering dengan langkah-langkah sebagai berikut:

- Menghitung persentase gabah padi (B) bernas, gabah hampa $(\mathrm{H})$, dan terserang walang sangit (TWS).
a. Gabah bernas (B) $=\frac{\text { jumlah biji bernas }}{\text { total jumlah gabah }}$
b. Gabah hampa $(\mathrm{H})=\frac{\text { jumlah biji hampa }}{\text { total jumlah gabah }}$
c. Gabah terserang walang sangit (TWS) $=\frac{\text { jumlah gabah terserang walang sangit }}{\text { total jumlah gabah }}$

- Menghitung potensi hasil padi/kg/ha (B) Potensi hasil padi $=$ berat satu butir padi x jumlah total gabah padi

- Menghitung estimasi potensi kehilangan hasil gabah akibat walang sangit
a. Persentase gabah bernas (B) $\mathrm{x}$ Potensi hasil padi $/ \mathrm{kg} / \mathrm{ha}$.
b. Persentase gabah hampa $(\mathrm{H}) \times$ Potensi hasil padi/kg/ha.
c. Persentase gabah terserang walang sangit (TWS) x Potensi hasil padi $/ \mathrm{kg} / \mathrm{ha}$

\section{Analisis Data}

Data hasil pengamatan dianalisa dengan menggunakan analisis sidik ragam (ANOVA) $(\alpha=$ $5 \%)$. Jika memperlihatkan pengaruh yang nyata, dilakukan uji dengan menggunakan Beda Nyata Jujur (BNJ) pada taraf kepercayaan 95\% menggunakan program SAS 9.1 (Statictical Analisys Sistem).

\section{Hasil}

Hasil sidik ragam menunjukkan perlakuan introduksi walang sangit dengan jumlah yang berbeda berpengaruh terhadap peubah padi terserang walang sangit, namun tidak berbeda nyata terhadap parameter persentase padi gabah bernas dan persentase padi gabah hampa (Tabel 1).
Tabel 1. Sidik ragam pengaruh serangan walang sangit dengan populasi yang berbeda terhadap peubah hasil gabah padi sawah di desa Kimak.

\begin{tabular}{|c|c|c|c|}
\hline \multirow{2}{*}{ Peubah } & \multicolumn{2}{|c|}{$\begin{array}{c}\text { Jumlah walang } \\
\text { sangit }\end{array}$} & \multirow{2}{*}{ KK $(\%)$} \\
\hline & F hit & $\operatorname{Pr}>\mathrm{f}$ & \\
\hline $\begin{array}{c}\text { Gabah } \\
\text { terserang } \\
\text { walang sangit }\end{array}$ & $8,06^{* *}$ & 0,0043 & 25,79 \\
\hline Gabah bernas & $3,11^{\text {tn }}$ & 0,0670 & 30,71 \\
\hline Gabah hampa & $0,52^{\text {tn }}$ & 0,8011 & 16,87 \\
\hline \multicolumn{4}{|c|}{$\begin{aligned} \text { Keterangan: } & { }^{*}=\text { berpengaruh sangat nyata pada } \\
& \text { taraf } 1 \%, *=\text { berpengaruh nyata pada } \\
& \text { taraf } 5 \%, \text { tn = berpengaruh tidak } \\
& \text { nyata, } \mathrm{Pr}>\mathrm{f}=\text { nilai probability, dan } \mathrm{KK} \\
& =\text { koefisien keragaman. }\end{aligned}$} \\
\hline
\end{tabular}

\section{Intensitas kerusakan mutlak (\%)}

Pengaruh perlakuan introduksi walang sangit dengan jumlah yang berbeda terhadap tanaman padi menyebabkan kerusakan secara mutlak atau sebesar $100 \%$ pada perlakuan penambahan walang sangit, karena disetiap plot terdapat gejala terserang walang sangit, kecuali pada perlakuan tanpa walang sangit (kontrol) dengan intensitas kerusakan mutlak sebesar $0 \%$.

\section{Intensitas serangan hama (\%)}

Intensitas serangan hama diperoleh dengan cara menentukan persentase dari tiap jumlah gabah per kriteria penilaian. Kriteria penilaian yang digunakan adalah gabah terserang walang sangit, gabah bernas dan gabah hampa (Gambar 1).

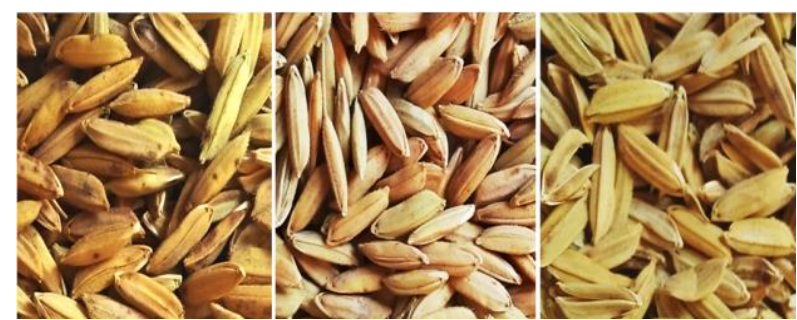

(a)

(b)

(c)

Gambar 1. Kriteria penilaian hasil padi: a) terserang walang sangit, b) bernas, dan c) hampa. (Dokumentasi pribadi 2018)

Persentase intensitas serangan walang sangit pada tiap perlakuan introduksi walang sangit terhadap hasil gabah padi disajikan pada Tabel 2 . Berdasarkan hasil uji lanjut Beda Nyata Jujur (BNJ) Tabel 2, Rerata persentase pengaruh serangan 
walang sangit berpengaruh nyata terhadap peubah gabah terserang walang sangit yaitu tertinggi pada perlakuan W7 infestasi walang sangit dengan jumlah 8 ekor per plot/kurungan tanaman padi berukuran $50 \mathrm{~cm}$ x $50 \mathrm{~cm}$, yaitu sebesar 28,98\% dan paling rendah yaitu pada perlakuan W1 atau infestasi walang sangit dengan jumlah 2 ekor sebesar $10,97 \%$.

Tabel 2. Rerata persentase pengaruh serangan berbagai jumlah walang sangit terhadap hasil gabah padi sawah di Desa Kimak.

\begin{tabular}{cccc}
\hline $\begin{array}{c}\text { Jumlah walang } \\
\text { sangit }\end{array}$ & $\begin{array}{c}\text { Gabah terserang walang sangit } \\
(\%)\end{array}$ & Gabah Bernas (\%) & Gabah hampa (\%) \\
\hline W0 (kontrol) & $0 \quad \mathrm{c}$ & $53,76 \mathrm{a}$ & $46,23 \mathrm{a}$ \\
W1 (2 ekor) & $10,97 \mathrm{bc}$ & $31,81 \mathrm{ab}$ & $57,22 \mathrm{a}$ \\
W2 (3 ekor) & $15,22 \mathrm{abc}$ & $32,31 \mathrm{ab}$ & $52,47 \mathrm{a}$ \\
W3 (4 ekor) & $17,15 \mathrm{abc}$ & $30,75 \mathrm{ab}$ & $52,10 \mathrm{a}$ \\
W4 (5 ekor) & $19,00 \mathrm{ab}$ & $25,36 \mathrm{ab}$ & $55,63 \mathrm{a}$ \\
W5 (6 ekor) & $22,14 \mathrm{ab}$ & $22,03 \mathrm{ab}$ & $55,82 \mathrm{a}$ \\
W6 (7 ekor) & $24,47 \mathrm{ab}$ & $16,23 \mathrm{~b}$ & $59,29 \mathrm{a}$ \\
W7 (8 ekor) & $28,98 \mathrm{a}$ & $23,27 \mathrm{ab}$ & $47,75 \mathrm{a}$ \\
\hline
\end{tabular}

Keterangan: Angka-angka yang diikuti oleh huruf yang sama pada kolom yang sama menunjukkan tidak berbeda nyata pada uji Beda Nyata Jujur (BNJ) pada taraf kepercayaan 95\%.

\section{Intensitas kerusakan relatif (\%)}

Kerusakan relatif atau kerusakan tidak langsung dan bertahap yang terjadi pada penelitian ini menunjukkan perbandingan antara tiap perlakuan. Intensitas kerusakan relatif yang diperoleh dengan cara skoring tingkat serangan, akan menghasilkan data yang lebih rinci dibandingkan dengan intensitas kerusakan mutlak. Berikut ini merupakan grafik batang yang menunjukkan ratarata intensitas kerusakan relatif yang terjadi pada berbagai perlakuan (Gambar 2).

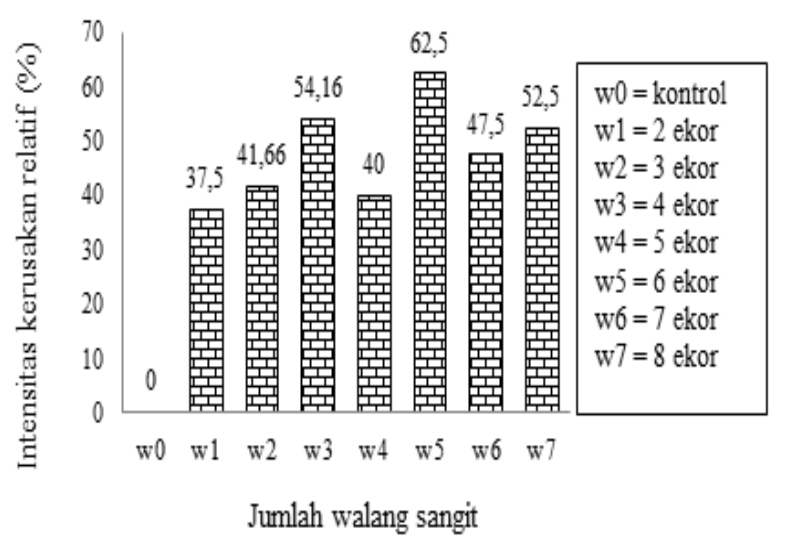

Gambar 2. Intensitas kerusakan relatif yang disebabkan oleh serangan hama walang sangit.
Estimasi potensi hasil produksi gabah dan kehilangan hasil akibat serangan walang sangit.

Berdasarkan hasil dari estimasi yang telah dilakukan, maka estimasi produksi gabah padi yang diperoleh dari petani padi sawah di desa Kimak adalah sebesar $\pm 6,0084$ ton/hektar. Hasil tersebut merupakan total produksi yang diperoleh jika tanaman padi bebas dari serangan hama maupun penyakit. Penelitian ini menunjukkan bahwa dengan adanya populasi walang sangit dalam jumlah yang berbeda akan mempengaruhi jumlah hasil gabah total. Pengaruh tersebut disajikan dalam Tabel 3.

Pengaruh serangan populasi walang sangit terhadap jumlah padi bernas yang diperoleh petani ditunjukkan dengan data pada Tabel 4. Kehilangan hasil akibat pengaruh dari serangan berbagai populasi walang sangit pada produksi padi bernas seperti yang terdapat pada Tabel 4 menunjukkan bahwa semakin tinggi populasi walang sangit, maka semakin besar persentase kehilangan hasil yang diperoleh. Pengaruh introduksi walang sangit dengan jumlah 8 ekor per plot mengakibatkan kehilangan lebih dari setengah produksi gabah bernas, sehingga dapat dikatakan petani akan mengalami kerugian yang cukup besar. 
Tabel 3. Estimasi pengaruh berbagai populasi walang sangit (ws) terhadap potensi panen padi sawah di desa Kimak.

\begin{tabular}{ccccc}
\hline Jumlah walang & \multicolumn{3}{c}{ Potensi hasil (ton) } & \multirow{2}{*}{ Kehilangan hasil (\%) } \\
\cline { 2 - 4 } Sangit & Terserang walang sangit & Padi Bernas & Padi hampa & \\
W0 (kontrol) & 0,000 & 3,203 & 2,806 & 0 \\
W1 (2 ekor) & 0,658 & 1,900 & 3,450 & 10,96 \\
W2 (3 ekor) & 0,927 & 2,065 & 3,017 & 15,42 \\
W3 (4 ekor) & 1,024 & 1,838 & 3,146 & 17,04 \\
W4 (5 ekor) & 1,182 & 1,488 & 3,338 & 19,67 \\
W5 (6 ekor) & 1,345 & 1,362 & 3,302 & 22,38 \\
W6 (7 ekor) & 1,379 & 1,327 & 3,302 & 22,96 \\
W7 (8 ekor) & 1,752 & 1,396 & 2,860 & 29,17 \\
\hline
\end{tabular}

Tabel 4. Estimasi persentase kehilangan hasil produksi padi bernas akibat pengaruh serangan dari berbagai populasi walang sangit (ws).

\begin{tabular}{ccccc}
\hline Jumlah walang & \multicolumn{3}{c}{ Jumlah padi (ton) } & \multirow{2}{*}{ Kehilangan hasil (\%) } \\
\cline { 2 - 4 } Sangit & Terserang ws & Padi bernas & Total & 0 \\
\hline W0 (kontrol) & 0 & 3,203 & 3,203 & 25,73 \\
W1 (2 ekor) & 0,658 & 1,900 & 2,558 & 30,97 \\
W2 (3 ekor) & 0,927 & 2,065 & 2,992 & 35,77 \\
W3 (4 ekor) & 1,024 & 1,838 & 2,862 & 44,26 \\
W4 (5 ekor) & 1,182 & 1,488 & 2,670 & 49,68 \\
W5 (6 ekor) & 1,345 & 1,362 & 2,707 & 50,97 \\
W6 (7 ekor) & 1,379 & 1,327 & 2,706 & 55,66 \\
W7 (8 ekor) & 1,752 & 1,396 & 3,149 & \\
\hline
\end{tabular}

\section{Pembahasan}

Data hasil sidik ragam (Tabel 1) menunjukkan pengaruh nyata antara populasi walang sangit terhadap gabah terserang, dan tidak berpengaruh nyata terhadap peubah gabah bernas dan hampa. Kerusakan yang terjadi pada biji padi akibat serangan walang sangit dicirikan dengan adanya titik hitam pada lapisan permukaan gabah yang kemudian akan menyebabkan mudahnya infeksi dari cendawan. Gejala serangan yang tampak terjadi karena tusukan mulut walang sangit yang kemudian menghisap cairan pada tiap bulir padi (Zakiyah et al. 2015).

Pratimi dan Soesilohadi (2011) menyatakan bahwa serangan walang sangit dapat menyebabkan biji padi menjadi kosong atau perkembangannya kurang baik serta berwarna coklat kehitaman. Pengamatan yang dilakukan pada seluruh sampel penelitian yang telah dipanen, menunjukkan bahwa dampak serangan yang ditimbulkan oleh walang sangit tidak mengosongkan biji, hanya setengah atau merusak sedikit bagian saja. Hal ini sejalan dengan penelitian Mandanayake et al.(2014) hilangnya cairan biji oleh serangan walang sangit menyebabkan biji padi menjadi mengecil tetapi jarang menjadi hampa, karena walang sangit tidak dapat mengosongkan seluruh isi biji yang sedang tumbuh.

Intensitas kerusakan mutlak yang terjadi pada gabah padi pada perlakuan W1 (2 ekor walang sangit), W2 (3 ekor walang sangit), W3(4 ekor walang sangit), W4 (5 ekor walang sangit), W5 (6 ekor walang sangit), W6 (7 ekor walang sangit) dan W7 (8ekor walang sangit) adalah sebesar 100\%. Sementara W0 memiliki intensitas kerusakan mutlak sebesar $0 \%$. Hal ini terjadi karena pada perlakuan W0 (kontrol) tanaman padi tidak diberikan perlakuan introduksi walang sangit, sedangkan perlakuan lainnya di tambahkan dengan walang sangit dengan jumlah yang berbeda. Perlakuan W0 digunakan untuk melihat perbandingan antara hasil tanaman padi dengan dan tanpa introduksi walang sangit.

Hasil penelitian menunjukkan bahwa pada seluruh perlakuan dengan introduksi walang sangit adalah mutlak terserang, namun untuk persentase kerusakan relatif seperti pada Gambar 2, menunjukkan data hasil yang berbeda tiap perlakuannya. Selain dari perlakuan W0 (kontrol), kerusakan relatif cenderung tidak terpengaruh oleh jumlah walang sangit, hal ini terlihat bahwa persentase kerusakan relatif w5 dengan jumlah walang sangit 6 ekor lebih tinggi dibandingkan 
dengan w7 dengan populasi walang sangit berjumlah 8 ekor. Faktor yang mempengaruhi fluktuatif dari persentase intensitas kerusakan relatif diduga terjadi karena beberapa faktor, yakni: faktor perbandingan populasi jantan dan betina, tingkat nafsu makan, serta faktor lingkungan.

Persentase jumlah serangga betina yang lebih besar akan menguntungkan bagi perbanyakan masal, dan untuk melakukan reproduksi, serangga betina akan membutuhkan sumber makanan lebih banyak dibandingkan dengan serangga jantan (Kakde et al. 2014). Selain dari reproduksi, perbedaan lain dari walang sangit jantan dan betina adalah pada panjang umur, menurut Hosamani et al. (2009) walang sangit betina memiliki rentang umur yang lebih lama yakni 35 - 80 hari, sementara walang sangit jantan hanya 23 - 61 hari.

Lingkungan akan mempengaruhi aktifitas serangga. Berdasarkan data Badan Meteorologi, Klimatologi, dan Geofisika (2018) kondisi lingkungan lahan penelitian periode bulan November - Desember pada waktu pengisian bulir pada padi sampai dengan masa panen menunjukkan bahwa kondisi iklim rata-rata curah hujan 415,1 mm, suhu udara sebesar $26,7^{\circ} \mathrm{C}$, dan kelembaban udara 84-86\%. Hosamani et al. (2009) menyatakan bahwa ekologi walang sangit adalah pada suhu kisaran 25,30-26,75 ${ }^{\circ} \mathrm{C}$, pada suhu minimum aktivitas serangga akan berkurang (turun). Sementara menurut Umboh et al. (2013) pada siang hari atau suhu maksimum, nimfa dan imago walang sangit akan berlindung dengan cara bersembunyi dibawah kanopi tanaman.

Persentase intensitas serangan hama walang sangit terhadap beberapa kriteria penilaian padi seperti yang terdapat pada Tabel 2, menunjukkan pengaruh persentase intensitas serangan walang sangit terhadap total hasil panen. Hasil uji lanjut BNJ dengan taraf kepercayaan 95\% menunjukkan rerata persentase pengaruh serangan walang sangit berpengaruh nyata terhadap peubah gabah terserang walang sangit. Semakin tinggi jumlah populasi, maka semakin besar persentase intensitas serangan hama.

Kehilangan hasil tergantung intensitas serangan pada bulir padi per malai, semakin tinggi intensitas serangan pada bulir, semakin tinggi kehilangan hasil padi. Hasil penelitian Mustikawati dan Asnawi (2011) menunjukkan populasi walang sangit 5 ekor / 9 rumpun padi akan menurunkan hasil 15\%. Jika dilihat dari Tabel 2 perlakuan W4 atau dengan introduksi 5 ekor walang sangit di dalam 8 rumpun tanaman adalah sebesar 19\%, maka penurunan hasil padi yang terjadi di desa Kimak lebih besar. Sementara untuk kisaran ambang ekonomi, berdasarkan data kehilangan hasil akibat walang sangit, yakni sebesar 15\%, maka untuk tanaman padi sawah di desa Kimak, serangan walang sangit dalam perlakuan W2 atau walang sangit berjumlah 3 ekor per plot ukuran $50 \mathrm{~cm}$ x $50 \mathrm{~cm}$ sudah mencapai ambang batas ekonomi dan sudah bisa dilakukan pengendalian oleh petani.

Hasil pengujian menunjukkan bahwa persentase gabah hampa berkisar antara 46,23\% hingga $59,29 \%$, dibandingkan dengan gabah bernas yang hanya $16,23 \%$ hingga $53 \%$, artinya persentase gabah hampa cukup tinggi (Tabel 2). Tanaman padi yang digunakan dalam penelitian ini adalah padi dengan varietas Inpago 8 dengan bentuk tanaman tegak, tinggi $\pm 122 \mathrm{~cm}$ (Yuniarti 2015). Fatimaturrohmah et al. (2016) menjelaskan bahwa secara umum malai yang panjang menghasilkan gabah yang banyak dan apabila tidak disertai dengan masa pengisian dan pemasakan gabah yang cepat akan menimbulkan kehampaan pada bagian pangkal malai.

Faktor lain selain varietas, yang mempengaruhi persentase padi hampa adalah teknik budidaya yang digunakan oleh petani seperti: pengolahan lahan, serangan hama dan penyakit. Menurut Satria et al. (2017) sistem pengolahan lahan yang tidak sesuai akan membuat tanaman padi kekurangan intensitas cahaya dan daun-daun mengering karena kekurangan asupan mineral. Penelitian Arinta dan Lubis (2018) menyatakan bahwa kerebahan mempengaruhi kehampaan bulir padi. Tanaman yang rebah menyebabkan pergelaran daun-daun menjadi tidak beraturan dan saling menaungi sehingga menyebabkan terganggunya proses pengangkutan hara mineral dan fotosintat ke arah biji padi.

Berdasarkan hasil estimasi potensi hasil produksi gabah dan kehilangan hasil akibat serangan walang sangit, maka produksi padi yang diperoleh dari petani padi sawah di Desa Kimak adalah sebesar $\pm 6,0084$ ton/hektar. Hasil tersebut merupakan total dari panen yang diperoleh bila tanaman padi tidak terserang walang sangit dan tidak ada padi yang hampa. Zakiyah (2015) menyatakan hubungan antara hasil panen dengan populasi hama dan intensitas serangan walang sangit adalah semakin tinggi populasi, makin tinggi intensitas serangan, dan semakin rendah kuantitas panen yang dihasilkan begitupula sebaliknya.

Pengaruh berbagai jumlah populasi walang sangit terhadap hasil gabah padi sawah di Desa Kimak seperti yang ditunjukkan pada Tabel 3, menunjukkan pengaruh populasi walang sangit terhadap potensi hasil panen (ton) gabah padi. Serangan walang sangit dengan rentang jumlah 2 hingga 8 ekor mampu mengakibatkan kehilangan hasil panen sebesar 10,96\% hingga 29,17\%. Hasil 
produksi padi pada dasarnya diperoleh dari banyaknya padi bernas, apabila persentase kehilangan dihitung dengan membandingkan data padi bernas dan padi terserang walang sangit, maka potensi kehilangan hasil oleh petani seperti yang ditunjukkan pada Tabel 4, dimana kehilangan hasil akibat serangan walang sangit lebih besar dengan rentang jumlah 2 hingga 8 ekor mampu mengakibatkan potensi kehilangan sebanyak $25,73 \%$ hingga $55,66 \%$.

\section{Kesimpulan}

1. Jumlah populasi walang sangit berpengaruh sangat nyata terhadap hasil gabah padi sawah di Desa Kimak, Kecamatan Merawang, Kabupaten Bangka.

2. Populasi 3 ekor walang sangit per plot $50 \mathrm{~cm} \mathrm{x}$ $50 \mathrm{~cm}$ mampu menurunkan hasil sebesar 15\% di Desa Kimak, Kecamatan Merawang, Kabupaten Bangka.

3. Persentase kehilangan hasil gabah padi sawah pada perlakuan 2 ekor sampai dengan 8 ekor populasi walang sangit adalah sebesar $10,97 \%$ sampai dengan $28,98 \%$.

\section{Daftar Pustaka}

[BMKG] Badan Meteorologi, Klimatologi dan Geofisika. 2018. Data Lingkungan Daerah Sungailiat Periode Bulan November Desember. Bangka: Badan Meteorologi, Klimatologi, dan Geofisika.

[BPS] Badan Pusat Statistik Provinsi Kepulauan Bangka Belitung. 2017. Provinsi Kepulauan Bangka Belitung dalam Angka 2017. Pangkalpinang: BPS Provinsi Kepulauan Bangka Belitung.

[Kementan] Kementrian Pertanian RI. 2018. Produksi, Luas Panen dan Produktivitas Padi di Indonesia, 2013-2017. http://www.pertanian.go.id/Data5tahun/TPA SEM-2017(pdf)/00-PadiNasional.pdf [4 Mei 2018].

[Kementan] Kementrian Pertanian RI. 2018. Produksi Padi Sawah Menurut Provinsi, 20132017.

http://www.pertanian.go.id/Data5tahun/TPA SEM-2017(pdf)/21-ProdPadiSawah.pdf [4 Mei 2018]

Arinta K, Lubis I. 2018. Pertumbuhan dan Produksi Beberapa Kultivar Padi Lokal Kalimantan. Bogor: Institut Pertanian Bogor. J. Agrohotri. 6(2): 260-270.

Dutta S, Roy N. 2016. Life Table and Population Dynamics of a Major Pest, Leptocorisa acuta
(Thunb.)(Hemiptera: Alydidae), on Rice and Non Rice System. India: M.U.C. Women's College. Int. J. Pure App. Bioci. 4(1): 199-207.

Fatimaturrohmah S, Rumanti I A, Soegianto A, Damanhuri. 2016. Uji Daya Hasil Lanjutan Beberapa Genotip Padi (Oryza sativa L.) Hibrida di Dataran Medium. Jawa Timur. Universitas Brawijawa. Jurnal Produksi Tanaman. 4(2): 129-136.

Hosamani V, Pradeep S, Sridhara S, Kalleshwaraswamy CM. 2009. Biological Studies on Paddy Earhead Bug, Leptocorisa oratorius Fabricius (Hemiptera: Alydidae). India: IDOSI Publication. Acad. J. Entomol . 2(2): 52-55.

Kakde AM, Patel KG, Tayade S. 2014. Role of Life Table in Insect Pest Management- a Review. India. Deptt. Of Entomology. College of Agriculture. IOSR Journal of Agriculture and Veterinary Science (IOSR-JAVS). 1(7): 40-43.

Lestari IE. 2017. Pengaruh Pola Tanam Padi (Oryza sativa L.) Kultivar Inpari Sidenuk terhadap Keanekaragaman Jenis Hama di Kelompok Tani Manunggal Patran Desa Madurejo. Yogyakarta: UNY. Jurnal Prodi Biologi. 6(7): 409-416.

Mandanayake MARA, Amarakoon AMA, Sirisena UGAI, Hemachandra KS, Michael RW, Kahawathatha. 2014. Occurrence of Leptocorisa acuta (Thunberg) (Hemiptera: Alydidae) in Sri Lanka. Sri Lanka. Entomology Division, Rice Research and Development Institute. J. Annals of Sri Lanka Depertment of Agriculture. 16: 323326.

Masauna ED, Tanasale HLJ, Hetharie H. 2013. Studi Kerusakan Akibat Serangan Hama Utama pada Tanaman Kacang Tunggak (Vigna unguiculata). Jurnal Budidaya Pertanian. 9(2): 95-98.

Mustikawati DR, Asnawi R. 2011. Serangan Walang Sangit dan Blas Leher pada Beberapa Galur Padi Hibrida Asal Cina Di Kebun Percobaan Natar Lampung. Balai Pengkajian Teknologi Lampung. J. Litbang Pertanian. Hal: 995-1000

Napitu B, Meiganati KB, Panjaitan BPP. 2012. Inventarisasi Hama Tanaman Jati Unggul Nusantara di Kebun Percobaan Universitas Nusa Bangsa Cogreg, Bogor. Journal Nusa Sylva 12(2): 35-46.

Pimsen T, Tibkaew AP, Rattahapan W. 2013. The Application of Geographic Information System (GIS) to Assess the Risk Area of Rice Bug (Leptocorisa oratorius (Fabricius)) Outbreak in Amphoe Paphayom and Amphoe Khuankanun, Phattahalung Province. GAMSARN International Journal. 7: 133-138.

Pratimi A, Soesilohadi RCH. 2011. Fluktuasi Populasi Walang Sangit Leptocorisa oratorius F. 
(Hemiptera: Alydidae) pada Komunitas Padi di Dusun Kepitu, Sleman, Daerah Istimewa Yogyakarta. Jurnal BIOMA. 13(2): 54-59.

Purnomo S. 2013. Populasi Walang Sangit (Leptocorisa oratorius Fabricius) di Kecamatan Sabak Auh Kabupaten Siak Provinsi Riau pada Tanaman Padi Masa Tanam Musim Penghujan. [skripsi]. Pekanbaru: Universitas Islam Negeri Sultan Syarif Kasim Riau.

Purwaningsih T, Kristanto BA, Karno. 2018. Efektifitas Aplikasi Beauveria Bassiana sebagai Upaya Pengendalian Wereng Batang Coklat dan Walang Sangit pada Tanaman Padi di Desa Campursari, Kecamatan Bulu, Kabupaten Temanggung. Semarang: Diponegoro University. J. Agro Complex. 2(1): 12-18.

Santoso RS. 2015. Asap Cair Sabut Kelapa sebagai Repelan Bagi Hama Padi Walang Sangit (Leptocorisa oratorius). Manado: Universitas Negeri Manado. Jurnal Sainsmat. 4(2): 81-86.

Satria B, Harahap EM, Jamilah. 2017. Peningkatan Produktivitas Padi Sawah (Oryza sativa L.) Melalui Penerapan Beberapa Jarak Tanam dan Sistem Tanam. Medan: USU Medan. Jurnal Agroteknologi FP USU. 5(3): 629-637.

Sihombing MAEM, Samino S. 2015. Daya Repelensi Biopestisida terhadap Walang Sangit
(Leptocorisa oratrius Fabricius) di Laboratorium. Malang: Universitas Brawijaya. Jurnal Biotropika. 3(2): 99-103.

Sudarjat. 2008. Hubungan antara Kepadatan Populasi Kutu Daun Persik (Myzuz persiciae Sulz.) dan Tingkat Kerusakan Daun dengan Kehilangan Hasil Cabai Merah (Capsicum annum L.). Jurnal Agrikultura.19(3): 191-197.

Umboh NT, Pinaria BAN, Manueke J, Tarore D. 2013. Jenis dan Kepadatan Populasi Serangga pada Pertanaman Padi Sawah Fase Vegetatif di Desa Talawaan Kecamatan Talawaan Kabupaten Minahasa Utara. Manado: Fakultas Pertanian Unsrat Manado. Jurnal Eugenia. 19(3): 1-9.

Yuniarti S. 2015. Respon Pertumbuhan dan Hasil Varietas Unggul Baru (VUB) Padi Gogo di Kabupaten Pandeglang, Banten. Banten: Balai Pengkajian Teknologi Pertanian Banten. J. BIODIV INDON. 1(4): 848-851.

Zakiyah F, Hoesain M, Wagiyana. 2015. Pemanfaatan Kombinasi Bau Bangkai Kodok dan Insektisida Nabati sebagai Pengendali Hama Walang Sangit (Leptocorisa acuta T.) pada Tanaman Padi. Jember. Universitas Jember. Jurnal Berkala Ilmiah Pertanian.1(1): 10-11. 